\title{
'Going Glocal': a qualitative and quantitative analysis of global citizenship education at a Dutch liberal arts and sciences college
}

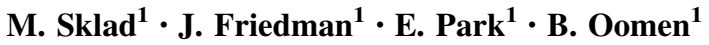

Published online: 9 December 2015

(C) The Author(s) 2015. This article is published with open access at Springerlink.com

\begin{abstract}
Over the past decades, more and more institutions of higher learning have developed programs destined to educate students for global citizenship. Such efforts pose considerable challenges: conceptually, pedagogically and from the perspective of impact assessment. Conceptually, it is of utmost importance to pay attention to both structural inequalities and intercultural competencies, to emphasize both differences and similarities. In addition, there is the need to increase awareness of the dialectics between the global and the local. Pedagogically, this calls for transformative learning, with an emphasis on attitudes and skills, in addition to knowledge alone. Once objectives have been defined and translated pedagogically, such programs call for an assessment of the degree to which they have been met. In this light, this article describes the conceptualization and pedagogics of an innovative project, Going Glocal, designed at a Dutch liberal arts and sciences college on the basis of these premises and its impact on the university students concerned.
\end{abstract}

Keywords Education for global citizenship - International education · Globalization . Impact assessment $\cdot$ Liberal arts

\section{Introduction}

The increase of global interdependence and the complex problems that result require solutions which are international in scale. This changing reality poses particular challenges for institutions of higher education. In order to better equip their students to function effectively in, and to contribute positively to, this changing world, universities have been increasingly attending to the development of intercultural competencies. They have also been focusing on developing in their students a willingness and ability to take on global

M. Sklad

m.sklad@ucr.nl

1 University College Roosevelt, Lange Noordstraat 1, 4331 CB Middelburg, The Netherlands 
challenges. Connecting the classroom to the world, and bringing the world into the classroom, has become a stated program outcome of more and more universities. These initiatives have led to activities ranging from merely stimulating student exchanges to the development of full-fledged service learning programs (Abdi 2008; Andreopoulos and Claude 1997).

Such programs directed towards education for global citizenship do pose considerable conceptual, pedagogical and methodological challenges. The concept of global citizenship, for one, goes far from unchallenged. There are many different understandings of it, ranging from an emphasis on critiques of the world's state of affairs to acceptance of power differentials and diversity, or even focusing purely on the intercultural competences needed to enter the global employment market (Abdi 2008; Peters et al. 2008; Shultz et al. 2011b; Andreotti 2006). In terms of pedagogics, it is evermore clear that experiential learning is very important in this field, although different viewpoints exist on whether the aim should be mere transactional service learning or truly transformational (Boland 2014). The best way to create significant learning experiences is not only open to discussion, but also subject to a lack of empirical data on the impacts of programs destined to strengthen education for global citizenship (Richardson et al. 2011). This, in turn, relates to questions concerning quality assurance, and the best ways of measuring the impact of programs that differ so significantly from other university courses.

It is with these challenges in mind that the Going Glocal program was designed to be taught at a small liberal arts and sciences college in the Netherlands. Before assessing the contribution of this program towards strengthening global citizenship, this article first discusses the rise of education for global citizenship in institutions of higher learning, before considering this trend in relation to liberal arts and sciences education more generally. Subsequently, we present the conceptualization of Going Glocal, the way in which its impact was assessed, and the lessons learned from it.

\section{Education for global citizenship in higher education}

Over the past decades, the drive towards more attention for civic education has expanded from a national focus to one that is more global in scale, and from attention for primary and secondary education towards institutions of higher learning. The shift toward such a focus at the tertiary level comes with the acknowledgement that universities also play 'an important, indeed seminal, formative role in the creation of citizens in almost all the countries of the world' (Shultz et al. 2011a, 1).

Generally, since the late 1980s there has been a growing interest in promoting civic engagement in Western democracies (Westheimer and Kahne 2004). This trend can be attributed to the challenges associated with globalization, multiculturalism, migration, the weakening of civic engagement and the breakup of social and family ties, among other things (Naval and Jover 2006). Involvement of educational institutions has been seen as a partial remedy to some of the problems arising. Many stakeholders agree that besides providing pupils with core subject knowledge, schools should fulfill civic functions as well, meaning that they have the responsibility to prepare students to become engaged citizens who contribute to their societies. Nowadays, civic education and related topics such as moral, democratic or social education are considered essential components of schooling. In recent years, civic education has been introduced into nearly all school systems in Europe (Eurydice 2005), the United States, Canada, and Australia (Print and Gray 2000). In the 
Netherlands, for instance, the Dutch Council of Education (Onderwijsraad) promotes the stimulation of the ability and motivation to participate in civic and political life, and the willingness and capacity of young people to contribute to society (Onderwijsraad 2003; NCDO 2013). As a result, since the beginning of 2006 all Dutch schools-public and private-are obliged to include civic education in their curricula (Inspectie van Onderwijs 2006).

Nevertheless, there is also a growing awareness that modern societies face increasingly global challenges which require more than just local or national civic competencies, but also global ones. The process of globalization and its challenges require concerted action on a global scale. Global citizens or "globally minded citizens" (Hanson 2010) view the world and its inhabitants as interdependent, and work to develop the capacity to act in order to advance both their own enlightened self-interest and the interest of people elsewhere in the world. Global citizens understand the interconnection of all living things (Appiah-Padi 2001), but also the inequalities and the disparities that characterize today's world; and they have the knowledge, attitudes and skills to address these disparities. New domains of education that prepare young people to tackle these global challenges successfully have been classified as global citizenship education or education for global citizenship (GCE/EGC), and they have been introduced all over the world (Andreotti et al. 2015; Mannion et al. 2011; Tchimino 2008). Definitions and understandings of the concept differ strongly, but UNESCO, in a recent influential report, stated that "Global Citizenship Education (GCE) is a framing paradigm which encapsulates how education can develop the knowledge, skills, values and attitudes learners need for securing a world which is more just, peaceful, tolerant, inclusive, secure and sustainable" (UNESCO 2014, 9).

Following an initial focus within primary and secondary education, more and more higher education institutions have now also included education for global citizenship in their mission (Peterson 2009). The American Association for Colleges and Universities (2015), for instance, recommends that the program outcomes and the learning objectives of the institutions represented explicitly include objectives such as: 'civic knowledge and engagement - local and global', and 'intercultural knowledge or competence' (Association for Colleges and Universities 2015). Many universities merely define their role as that of stimulating diversity in the student body and encouraging student exchanges, as well as encouraging attention for global issues (Doer 2013). Even amongst the scholars and institutions that do seek to stimulate deeper, more transformative learning experiences, the type of learning to be stimulated remains hotly debated (Shultz et al. 2011a). The general acknowledgement that global citizenship education concerns the knowledge, attitudes and skills related to functioning as a citizen of the world, after all, still leaves room for a variety of interpretations. Starting with the type of knowledge to be stimulated, for instance, Shultz sets out how 'at its best, global citizenship education speaks to how humanity might organize itself to address the very critical issues of this time and how this can happen through just political, economic and social relations with a consideration of the global/globalized context for such education'. She then maps the differences in the degree of structural analyses and intercultural foci that underpin efforts to do so (Shultz 2011, 13). For its part, UNESCO calls for equipping students to 'acquire knowledge, understanding and critical thinking about global, regional, national and local issues and the interconnectedness and interdependency of different countries and populations' (2015, 15). Still, the degree to which students learn about similarities or differences, the status quo or structural inequalities is open to much discussion and varied interpretation.

The same applies where it concerns attitudes, especially the socio-emotional element of the knowledge-attitudes-skills triad. In terms of attitudes, then, education for global 
citizenship might, as UN Secretary General Ban Ki Moon put it, give us 'a profound understanding that we are tied together as citizens of the global community, and that our challenges are interconnected'. However, such an understanding can still foster acceptance or anger, emphasize altruism or the notion of inalienable rights and related responsibilities (UNESCO 2015, 12). Dower and Williams $(2002,254)$ write of a change in perspective that is related to a 'root moral commitment to some form of cosmopolitanism'. In terms of skills, cosmopolitanism can work towards intercultural understanding (for instance, via language skills), but also stimulate students toward concerted citizen action that leads to a readjustment of existing inequalities. Here, it is important to realize that, especially for universities, normative ideals can have an uneasy relationship with the critical thinking that is valued at universities. The choices made in the context of the Going Glocal program will be discussed below, but it is clear that many other understandings of education for global citizenship are also possible, each with different pedagogics and intended outcomes.

\section{The liberal arts and sciences context}

More and more institutions of higher education emphasize global citizenship, but such an approach fits particularly well within liberal arts and sciences colleges. Such colleges have traditionally considered their mission not only to transmit knowledge, but also to shape citizens of the world. As such, the liberal tradition dates back to ancient Greece. Seneca emphasized the importance of freeing the mind via a liberal education as a means to 'cultivate humanity'; Plato focused on the importance of responsible citizenship; and Aristotle pled for the cultivation of liberally educated, rational individuals who can use reason to make decisions in society (Seneca and Costa 1988, Letter 88; Aristotle and Lord 2013). With the development and institutionalization of the tradition in the United States via the founding of colleges like Harvard and William and Mary in the 17th century, attention to the formation of public intellectuals was also incorporated. John Dewey, for instance, held the idea that liberal education should lead to 'hospitality of mind, generous imagination, trained capacity of discrimination, freedom from class, sectarian or partisan prejudice and passion, faith without fanaticism' (Dewey and Boydston 1980, 201). In recent defense of liberal education in the United States, many are pointing out the value of liberal arts and sciences colleges in educating 'citizens of the world' (Nussbaum 1997, 2010; Roth 2014).

Whereas liberal arts and sciences colleges have been part of the American university landscape since the 17th century, they are a relatively new phenomenon in the Netherlands, and in Europe more generally (Nussbaum 2002; van der Wende 2011). In the Netherlands, liberal arts and sciences colleges are classified as University Colleges, designated to underline their selective nature, residential and international character, small scale and emphasis on community. The University College Roosevelt (UCR), discussed in this article, is one of the seven Dutch University Colleges (University Colleges Deans of the Netherlands 2015). It is part of Utrecht University, a large research university, but is based $200 \mathrm{~km}$ away in the province of Zeeland. The College is named after Theodore, Franklin and Eleanor Roosevelt and is committed to carrying forward their legacy of internationalism, social justice and human rights. The 600 students who follow a liberal arts and sciences bachelor program at UCR come from all over the world, but are also actively engaged in the local community during the three years of their bachelor program via 
undergraduate research and community projects. In this sense, UCR is a 'civic university' that fosters its connections with the outside world (Benson and Harkavy 2000).

\section{The Going Glocal program}

The aim of UCR's Going Glocal program is to strengthen students' knowledge, attitudes and skills in the field of global citizenship. Its name is based on the notion of glocalization, the observation that all global change starts with local action, and the recognition that there is always an underlining connection between local and global processes. The notion of glocalization thus draws attention to the extent to which the local is constitutive of the global (and vice versa), and the degree to which the relationship between localities and the global is dialectical rather than unidirectional (Bauman 1998; Robertson 1995). This translates into a pedagogy that emphasizes the importance of UCR's inherently internationally-focused student body also rooting locally, in the sense of learning about local issues, establishing connections with the local population and actively contributing to the community. In seeking to take action on issues of social justice, students often tend to prefer voluntourism: travelling to an Indian orphanage instead of working at a local shelter (Jakubiak 2012). The designers of the Going Glocal program deemed it essential to also transmit the importance of rooting locally, and taking responsibility for connecting global issues to one's own community (Guimaraes-Iosif 2011, 83; Freire 2004). As such, the program seeks to strengthen not only knowledge, but also the attitudes and skills needed to address global problems through local action.

As discussed above, one key challenge defined in the critical literature on education for global citizenship is to avoid reinforcing existing binaries between the 'developed' North and the 'underdeveloped' South. Instead, it is important to critically challenge students' assumptions and worldviews, and thus to open the way toward true transformational learning (Guimaraes-Iosif 2011). One of the key critiques of many education for global citizenship programs is that they reproduce essentialistic, ethnocentric, Eurocentric and imperialistic assumptions instead of problematizing them (Andreotti 2011, 140). In developing the program, it was deemed very important to not reinforce stereotypes, but to ensure that they were thoroughly dismantled.

On the basis of these insights a program was designed in which groups of 15 students take part in three learning modules over the course of an entire academic year. The three modules equate to two regular UCR social science courses (each 7.5 ECTS), and can be used to fulfill degree requirements. Interested students apply to the program and undergo a selection process, including a written application and interview. During the course of the program students are guided by a socio-cultural anthropologist and a human geographer with long-standing experience in Namibia, as well as by a lecturer of pedagogy.

The first module, comprising 60 contact teaching hours and 150 self-study hours, begins as a regular course on the first day of the spring term. Often, at the start of the course, participating students hold misconceptions concerning their role and the nature of the program. Many expect to be setting out on an adventure in 'Africa' where they will 'help' those in need. Even before introductions, students are given their first assignments, two inclass essays: 'this is what I know about Africa' and 'this is what I know about Namibia'. Once completed, they submit them in a sealed envelope marked with their names.

During the first few minutes of that initial meeting the participants are informed that they will not be travelling to Namibia 'to help', but rather 'to share': to share time and 
space with their Namibian peers and to share themselves with others, all the while unlearning and re-learning as they go. The program is meant as a dialogue, an exchange, not an act of consumption. It is a point that is re-enforced time and time again throughout the course.

In a similar spirit, the lecturers introduce a reversal of the traditional pedagogic order in the classroom by incorporating elements of problem-based learning, peer teaching, group work and independent research on topics of the student's own choosing. The lecturers relinquish much of their authority. They fulfill the role of facilitators of dialogue and exchange, moderators, and creators of learning opportunities. They will challenge ideas often, and directly so, but they won't impart knowledge.

During the first module it is not only the pedagogic approach that aims to generate critical thinking and 'unlearning', but it is also the interdisciplinary and critical nature of the course content itself. Students begin by exploring the contested notions of 'youth', 'development', and modernity/tradition. For nearly two months, they are exposed to different ways of thinking about some of the normative ideas that have dominated, often silently so, their own reflections on the world. What are the popular constructions of 'youth' in the so-called West (Wyn and White 1997; Ansell 2005)? Are these models relevant to other social and cultural contexts (De Boeck and Honwana 2005)? In what ways do societal and cultural constructions of youth affect the lives of young people (Mufune 2002)? What constitutes 'progress' and who has the right to decide? How has 'development' been defined (Arndt 1987; Meillassoux 1974; UNDP 1990; Sachs 1992; Sen 1999)? How have the ideas and practices associated with modernity helped to produce 'development'? What is 'tradition' and what is its relationship with modernity (Gusfield 1967)?

These social scientific problems are then embedded within a post-colonial African context through a body of literature and ideas that help students orientate geographically, historically and epistemologically. In what ways have scholars approached the study of modernity in Africa (Geschiere et al. 2008; Comaroff and Comaroff 1993)? What does it mean to be 'modern' or 'traditional' there (Ferguson 2006)? Why, in the post-colonial African context, should modernity be understood relationally (Probst et al. 2002)?

During the second half of the pre-course, students undertake an extensive survey of Namibian studies in further preparation for the summer field trip. They study, discuss and teach one another the history of Namibia in the world, and they reflect on its colonial and apartheid past. Topics relating to contemporary Namibian culture, society and politics are also considered. By the middle of the term, students begin their guest teaching in local primary and secondary schools. Following the content of their university course, they develop original learning materials as a way to share their emerging insights with local primary and secondary school pupils. This additional task extends the outreach of the program and increases its potential impact on the primary recipients (university students). According to cognitive dissonance (Festinger 1957), and based upon the hypocrisy induction paradigm, participants lecturing about benefits of a certain behavior become more motivated to behave in that way themselves (Aronson 1992, 1999).

Finally, it is important to mention that during these first four months of the program students are never formally exposed to the concept of 'global citizenship'. The notion is neither raised nor uttered during class meetings, and students spend little to no time reflecting on what might constitute such a citizen. By the end of the spring semester students certainly have not been able to completely 'unlearn' a lifetime of stereotypes about 'the other' and about 'Africa' (that's impossible), but they have been confronted with the situated nature of their knowledge, something that will need to be drawn upon during and after their field trip to Namibia. 
The program's second module takes place during the summer vacation period. The students spend four weeks living in the town of Opuwo, Namibia (pop. 7000), located in the rural, north-western part of the country. During the first formal gathering of the group, the lecturers insist that students discard all of their newly learned theory: "The field trip is about experience and practice, not big ideas, not thinking. Be here. Share. Have fun" they are told.

Each morning, the students serve as assistants in local schools or as interns at a youthfocused community-based organization; and each afternoon, they work in collaboration with a group of young Namibians in order to complete together a community project at the local youth center. The task of taking part in the daily functioning of a local school or organization, as well as working together with local youth on a shared project, offers the opportunity for students to engage in a process of 'structured hanging-out'. 'The emphasis here lies not on the importance of completing tasks or work (the 'structure'), but rather on the informal interactions that take place around it. In addition to these two main activities, UCR students and Opuwo youth share time together during the evenings (dancing in local clubs, talking together, cooking), and on weekends they journey together to local tourist spots for fun and relaxation, or they head to the village with one of their new friends.

Throughout the field trip UCR students keep a journal. There is no strict format or expectations for its completion; students maintain it in a way that makes most sense to them. Daily entries afford them the space and purpose to reflect on their experiences. In their journals they recount the day's events, detail what they have learned or the challenges faced and/or overcome; they note emerging ideas, reflect on their learning, and they unload frustrations and difficulties. The journal becomes a record of the student's experiences in Namibia. In it, they negotiate the challenges presented by the new context and social environment, by the relative deprivation, by the experience of gender and age inequalities, and by the color of their own skin. In addition to this intra-personal reflection process, the lecturers hold daily 90-minute group supervision sessions in an informal setting. During these meetings, students share their personal issues, challenges, experiences, ideas, and feelings with the group. Students sometimes cry or argue with one another; and, after the first two or three sessions, they begin referring to these supervisions as 'group therapy'.

On the last day of the field trip, the lecturers hand the students their original essays in the sealed envelopes. They open and read their own essays. Many laugh; others blush with embarrassment. A few share their early ideas with the rest of the group. In this way, the students re-visit their starting points, and recognize the steepness of their individual learning curves. Most have come a long way.

The third and final module takes place during the subsequent fall semester in The Netherlands. The semester is dominated by the students return to the local schools where they follow-up on their previous teaching. This time, though, they are able to teach classes based on the practical experiences they have had in Namibia. During this part of the program, students develop additional teaching materials which are eventually distributed to all primary and secondary schools in the province. The materials vary: short films, children's books, pamphlets, sample lesson plans, a school newspaper, a compilation of stories written by children in Opuwo for their peers in The Netherlands.

In addition, during the fall semester UCR students write a reflection paper about their experiences in the program. It is here, in that written space, where they are asked to

\footnotetext{
1 This latter element sought to apply the findings of a classical psychological study by Sherif et al. (1961/ 1988): mutual interdependence, a common goal, and a friendly informal atmosphere along with equal status and contact with multiple out-group members are among catalysts of prejudice reduction.
} 
synthesize their book learning (theory) with their lived experiences (practice). They consider how the experience helped shape their understanding of the concepts central to the preliminary course ('development', youth, tradition and modernity, progress), and how those same concepts helped or hindered them in trying to understand the lives of their new friends in Namibia?

The above two exercises - teaching about the issues they encountered while in Namibia, and reflecting in written form about their experiences-prove a powerful means that enable students to continue actively engaging and reflecting on their own learning. When one is forced to translate knowledge gained through lived experience into the spoken or written word for the benefit of others, then one is inevitably continuing to learn from an experience that has already passed. This final module of the program helps global citizenship take root more firmly at home.

\section{Assessing the impact of the program}

To avoid bias, neither the designers of the program nor the university personnel directly involved in teaching ${ }^{2}$ were involved in the evaluation process, in conducting and interpreting the interviews, or analyzing the results. In this way, the evaluation of the program was separated from its implementation. The program was evaluated both quantitatively and qualitatively.

There is little work on understanding the impact of global citizenship programming on students (Richardson et al. 2011, 97), and even fewer studies have controlled designs adequately enough to document the added value of such global citizenship programs. Those that have are almost exclusively focused on regular study abroad programs (Tarrant et al. 2014). This paper focuses on the effects of the Going Glocal program ${ }^{3}$ in quantitative terms. Qualitative evaluation is limited here to a content analysis of post intervention interviews, with an emphasis on changes mentioned spontaneously by participants and the match between those transformations and intended program outcomes.

The effects of the program were assessed in multiple forms. Firstly, upon entering and leaving the program participating university students completed a global citizenship measurement instrument. Scales adopted for use in the study included the Global Citizenship Scale (Morais and Ogden 2011), the Cross-Cultural World-Mindedness Scale adopted from a scale to Measure World-Minded Attitudes (Sampson and Smith 1957; DerKarabetian and Metzer 1993), the Intercultural Communication Competence scale (Arasaratnam 2009), a cultural intelligence scale (Ang et al. 2007), the Civic Competence Scale (ten Dam et al. 2011), and a UCR Global Perspective Scale (GPS) that was designed specifically for the program. The GPS consists of 21 seven-point Likert scale items that assess the presence of attitudes, skills and knowledge required for recognizing levels of global interconnectivity and the links between local and global processes (e.g. social, economic, political, environmental). The scale also measures the presence of such attitudes, skills, and knowledge in relation to action, in particular, action directed towards achieving global justice and equality. The items were designed and evaluated in terms of face construct validity by an expert Delphi group, and piloted before application. The GPS demonstrated good psychometric reliability (see Table 1 and Table 2).

\footnotetext{
2 Authors 2 and 4.

3 An analysis of the transformative learning process of the program utilizing excessive qualitative thematic analysis has been published elsewhere (de Koeijer et al. 2015; Weistra et al. 2015).
} 
Table 1 Reliability analysis

\begin{tabular}{lll}
\hline Assessment measure & Pre-test $\alpha$ & Post-test $\alpha$ \\
\hline UCR Global Perspective Scale & 0.90 & 0.89 \\
Intercultural Communication Competence & 0.77 & 0.53 \\
Global Citizenship-Social Responsibility & 0.56 & 0.69 \\
Global Citizenship-Global Competence & 0.60 & 0.60 \\
Global Citizenship-Global Civic Engagement & 0.74 & 0.82 \\
Intercultural Communication Competence (Abbreviated) & 0.78 & 0.68 \\
Cultural Intelligence (Metacognitive) & 0.79 & 0.76 \\
Cultural Intelligence (Cognitive) & 0.82 & 0.75 \\
Cultural Intelligence (Motivational) & 0.83 & 0.76 \\
Cultural Intelligence (Behavioral) & 0.82 & 0.91 \\
Cross-Cultural World Mindedness (CWM) & 0.81 & 0.87 \\
Total $N=26$ & 26 & 22 \\
\hline
\end{tabular}

Scores of the intervention group were compared to the scores of a comparison group consisting of students at the same college who did not participate in the program. In addition, recipients of the program participated in a series of individual semi-structured, indepth interviews and filled out quantitative paper-and-pencil evaluation forms for each module. Also, school pupils involved in the outreach part of the program completed evaluation questionnaires relating to the classes that had been taught by the university students. Due to the length of the program and the fact that it was spread between two consecutive academic years, and due to the nature of the Dutch school system in general, only a portion of the school children participated in both spring and autumn modules. Finally, given the large age span of the participating school children, two different ageappropriate forms were used. Children in classes with an average age below 12 received a simpler version of the questionnaire that was administered to teenagers.

Data were collected from 15 university students in the intervention group and ten in the control group. Both groups consisted mainly of females $(>75 \%)$. The oldest participant was 24 years old, the youngest was 21; seven participants were born in the Netherlands and four outside of Europe. Twelve of them had the Dutch nationality, and three possessed a double nationality. The comparison group was similarly diverse.

The initial analysis indicated that the majority of scales had a satisfactory reliability, as measured by internal consistency coefficient alpha (see Table 1) and test re-test reliability (see Table 2). The Global Perspective Scale demonstrated good convergent validity showing substantial correlations with all other measures of global citizenship competency used, both at pre-test and post-test (see Table 2). GPS correlated especially high with the Global Competence subscale of the Global Citizenship Scale (Morais and Ogden 2011).

Results of the pre-post intervention comparisons (see Table 3) indicated that students in the intervention group significantly improved on the UCR Global Perspective Scale $(t(11)=3.29, p<0.005)$ (see Fig. 1$)$, on Social Responsibility $(t(14)=2.58, p<0.05)$, and on Morais and Ogden's Global Competence sub scale $(t(14)=2.14, p=0.05)$.

Students who enrolled in the program already had somewhat more favorable scores than the comparison group before the intervention (see Table 3). In order to determine if participation in the program increased students' global citizenship scores significantly more than those at the same international university college who did not take part in the 
Table 2 Inter-correlations of the scales

\begin{tabular}{|c|c|c|c|c|c|c|c|c|c|c|}
\hline Assessment measure & $\begin{array}{l}\text { UCR } \\
\text { GPS }\end{array}$ & $\begin{array}{l}\text { GC- } \\
\text { SR }\end{array}$ & $\begin{array}{l}\text { GC- } \\
\text { GC }\end{array}$ & $\begin{array}{l}\text { GC- } \\
\text { GCE }\end{array}$ & ICC & $\begin{array}{l}\text { CQ- } \\
\mathrm{MC}\end{array}$ & CQ-C & $\begin{array}{l}\text { CQ- } \\
M\end{array}$ & $\begin{array}{l}\text { CQ- } \\
\text { B }\end{array}$ & CWM \\
\hline $\begin{array}{l}\text { UCR Global Perspective } \\
\text { Scale UCR GPS }\end{array}$ & 0.77 & 0.31 & 0.60 & 0.46 & 0.37 & 0.30 & 0.66 & 0.36 & 0.46 & 0.20 \\
\hline $\begin{array}{l}\text { Global citizenship- } \\
\text { social responsibility } \\
\text { (GC-SR) }\end{array}$ & 0.26 & 0.74 & 0.02 & 0.19 & 0.15 & 0.08 & 0.33 & 0.02 & 0.20 & 0.29 \\
\hline $\begin{array}{l}\text { Global citizenship- } \\
\text { global competence } \\
\text { (GC-GC) }\end{array}$ & 0.56 & 0.37 & 0.27 & 0.38 & 0.65 & 0.25 & 0.35 & 0.38 & 0.25 & -0.31 \\
\hline $\begin{array}{l}\text { Global citizenship- } \\
\text { global civic } \\
\text { engagement (GC- } \\
\text { GCE) }\end{array}$ & 0.19 & -0.08 & 0.40 & 0.32 & 0.13 & -0.19 & 0.48 & 0.23 & 0.26 & -0.12 \\
\hline $\begin{array}{l}\text { Intercultural } \\
\text { communication } \\
\text { competence (ICC) }\end{array}$ & 0.27 & 0.18 & 0.26 & 0.15 & 0.73 & 0.20 & 0.31 & 0.52 & 0.14 & -0.16 \\
\hline $\begin{array}{l}\text { Cultural intelligence- } \\
\text { metacognitive (CQ- } \\
\text { MC) }\end{array}$ & 0.20 & 0.10 & 0.35 & 0.73 & 0.04 & 0.18 & 0.21 & 0.11 & 0.23 & 0.21 \\
\hline $\begin{array}{l}\text { Cultural intelligence- } \\
\text { cognitive (CQ-C) }\end{array}$ & 0.31 & 0.16 & 0.22 & 0.15 & 0.25 & 0.25 & 0.66 & 0.17 & 0.18 & 0.30 \\
\hline $\begin{array}{l}\text { Cultural intelligence-- } \\
\text { motivational CQ-M }\end{array}$ & 0.38 & -0.22 & 0.29 & 0.27 & 0.26 & 0.14 & -0.08 & 0.46 & 0.31 & 0.06 \\
\hline $\begin{array}{l}\text { Cultural intelligence- } \\
\text { behavioral (CQ-B) }\end{array}$ & 0.46 & -0.02 & -0.10 & 0.30 & 0.01 & 0.44 & 0.44 & 0.02 & 0.40 & -0.07 \\
\hline $\begin{array}{l}\text { Cross-cultural world } \\
\text { mindedness }(\mathrm{CWM})\end{array}$ & 0.40 & 0.55 & 0.36 & 0.10 & 0.10 & 0.38 & -0.11 & 0.18 & 0.33 & 0.65 \\
\hline
\end{tabular}

Above diagonal: correlations at the pre-test. Below diagonal: correlations at the post-test. On diagonal: testretest reliabilities. $N=26$

program, participants' scores were compared to those of a control group. Covariance analysis of the UCR Global Perspective Scale revealed a statistically significant effect at post-test $(F(1,18)=4.60, p<0.05)$, controlled for pre-test-scores; and a marginally significant effect $(F(1,20)=4.32, p=0.05)$ in relation to global competence at post-test, controlled for pre-test-scores. The other effects were not statistically significant.

Participants evaluated the program at the end of the first and third modules, and the results were very positive. On a scale of 1 to 5 , with 5 denoting "very good", the program received an average score of $4.67(S=0.48)$. The vast majority of participants agreed that they had learned a great deal and that their interest in the subject increased as a consequence of the course (see Fig. 2 for distributions of answers).

Students were generally positive about having achieved the learning outcomes as set by the program, the exception being that they were uncertain about having been able to put global citizenship into practice (see Table 4). When it came to sharing their experiences with school children, the participants were optimistic about having encouraged their pupils to perceive similarities between themselves and children in Namibia, and about having been able to suspend some degree of judgment about others. However, the participants felt neutral about whether or not they had managed to help school children better understand their relationship with foreigners in distant countries (see Table 5). 
Table 3 Means and (standard deviations) of indicators for control and intervention groups

\begin{tabular}{|c|c|c|c|c|c|}
\hline \multirow[t]{2}{*}{ Assessment measure } & \multicolumn{2}{|c|}{ Control group $(n=10)$} & \multicolumn{2}{|c|}{ Intervention group $(n=15)$} & \multirow{2}{*}{$\begin{array}{l}\text { Effect } \\
d\end{array}$} \\
\hline & Pre-test & Post-test & Pre-test & Post-test & \\
\hline UCR GPS Perspective Scale & $5.47(0.43)$ & $5.67(0.29)$ & $5.80(0.65)$ & $6.18(0.56)$ & 0.31 \\
\hline GC-SR & $3.78(0.61)$ & $3.92(0.65)$ & $4.15(0.42)$ & $4.44(0.43)$ & 0.29 \\
\hline GC-GC & $3.51(0.37)$ & $3.52(0.28)$ & $3.53(0.50)$ & $3.82(0.37)$ & 0.63 \\
\hline GC-GCE & $2.35(0.23)$ & $2.74(0.47)$ & $2.83(0.38)$ & $2.69(0.56)$ & -1.32 \\
\hline ICC & $5.29(0.68)$ & $5.16(0.65)$ & $5.05(1.07)$ & $5.21(0.72)$ & 0.31 \\
\hline CQ (Metacognitive) & $5.33(0.61)$ & $5.18(1.26)$ & $5.30(1.10)$ & $5.27(0.81)$ & 0.13 \\
\hline CQ (Cognitive) & $4.45(0.76)$ & $4.88(0.69)$ & $4.72(1.11)$ & $4.98(0.86)$ & -0.17 \\
\hline CQ (Motivational) & $6.02(0.98)$ & $6.00(0.61)$ & $6.14(0.72)$ & $6.16(0.80)$ & 0.05 \\
\hline CQ (Behavioral) & $5.06(1.02)$ & $5.22(0.95)$ & $5.54(0.83)$ & $5.52(1.90)$ & -0.20 \\
\hline CWM & $4.48(0.45)$ & $4.38(0.47)$ & $4.67(0.37)$ & $4.63(0.43)$ & 0.15 \\
\hline
\end{tabular}

UCR GPS UCR Global Perspective Scale, GC-SR global citizenship (social responsibility), GC-GC global citizenship (global competence), GC-GCE global citizenship (global civic engagement), ICC intercultural communication competence, $C Q$ cultural intelligence, $C W M$ cross-cultural world mindedness

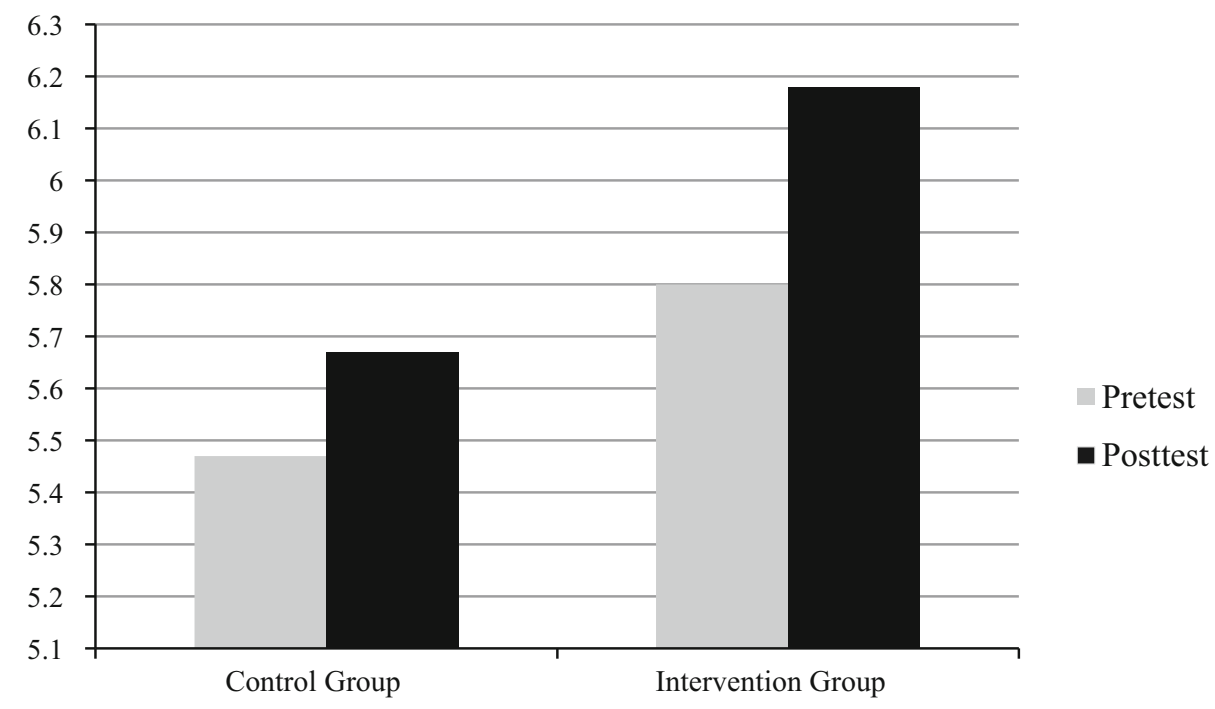

Fig. 1 The UCR Global Perspective Scale

The content analysis of in-depth interviews focused on what students gained from their experiences in Namibia and what they had hoped to share with the school children. The analysis revealed a number of primary themes: similarities between Namibians and "us", global interconnectedness, accepting others' perspectives as valid, thinking (critically), and fairness (see Table 6).

In assessing the impact of the program in the local schools, the lessons delivered by students during the first module were evaluated positively by the 176 school children who completed the class evaluation form (see Table 7). 


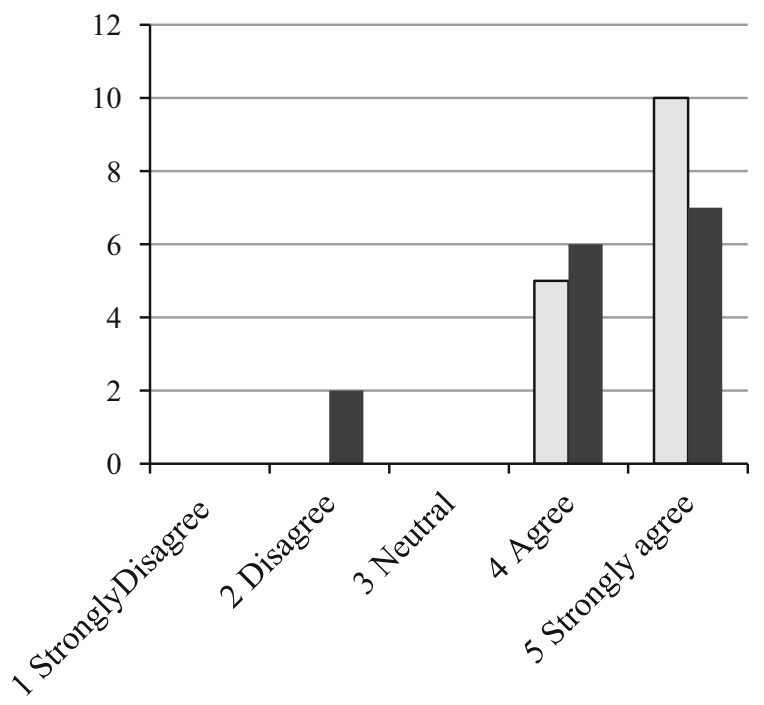
$\square$ I learned a great deal in this course.

My interest in the subject matter has increased as a consequence of this course

Fig. 2 Students' program evaluations

Table 4 Self-reported own learning objectives

\begin{tabular}{|c|c|c|c|}
\hline Description of objective & Number & Mean & $\begin{array}{l}\text { Standard } \\
\text { deviation }\end{array}$ \\
\hline $\begin{array}{l}\text { I have learned about similarities and differences between me and the } \\
\text { people in the country we visited }\end{array}$ & 14 & 5.86 & 1.23 \\
\hline I have learned how to apply Global Citizenship in practice & 13 & 3.54 & 1.51 \\
\hline $\begin{array}{l}\text { I have gained insight into the complexity of development aid in the } \\
\text { country we visited }\end{array}$ & 14 & 6.07 & 1.14 \\
\hline I have gained insight into the perceptions of local people & 14 & 6.00 & 0.78 \\
\hline I have learned about other people's perspectives & 14 & 6.14 & 0.36 \\
\hline I learned how to communicate about Global Citizenship issues & 14 & 4.50 & 1.45 \\
\hline $\begin{array}{l}\text { I have gained a better understanding of the importance of locality to } \\
\text { Global Citizenship }\end{array}$ & 14 & 4.64 & 1.74 \\
\hline $\begin{array}{l}\text { I have become more aware of stereotypes of other countries (Namibia) in } \\
\text { my own culture }\end{array}$ & 15 & 5.73 & 1.49 \\
\hline I have learned about mechanisms sustaining global social inequality & 15 & 5.47 & 0.99 \\
\hline I have gained insight into different perspectives about the world & 15 & 5.87 & 0.92 \\
\hline
\end{tabular}

Scale ranging from 1 ("strongly disagree") to 7 ("strongly agree")

Following the participating students' return from Namibia, the third module conducted in local schools was also received positively: on a scale from one to ten, as traditionally used in Dutch educational institutions, 238 pupils graded their interest in the lessons 7.43 $(s=2.07)$, and they reported having achieved a high level of learning, with a score of 7.30 $(s=2.25)$ on average. They were also positive about having achieved the stated learning objectives (see Table 8 for details). 
Table 5 Students' self-reported pupils' learning objectives

\begin{tabular}{|c|c|c|c|}
\hline Learning objective & Number & Mean & $\begin{array}{l}\text { Standard } \\
\text { deviation }\end{array}$ \\
\hline $\begin{array}{l}\text { Children learned about the similarities between people from Namibia and } \\
\text { people from the Netherlands }\end{array}$ & 14 & 5.50 & 1.40 \\
\hline $\begin{array}{l}\text { Children learned about the resemblance between the daily lives of people } \\
\text { in Namibia and people in the Netherlands }\end{array}$ & 14 & 5.43 & 1.34 \\
\hline $\begin{array}{l}\text { Children learned that social inequality is an everyday reality for many } \\
\text { people }\end{array}$ & 13 & 4.69 & 1.75 \\
\hline $\begin{array}{l}\text { Children learned about how consumption in the West contributes to } \\
\text { social inequality }\end{array}$ & 13 & 3.31 & 1.84 \\
\hline $\begin{array}{l}\text { Children learned about aspects of the unequal relationship between } \\
\text { Africa and the West }\end{array}$ & 14 & 4.29 & 1.68 \\
\hline $\begin{array}{l}\text { Children learned not to judge people on a first instance, but to open up to } \\
\text { other perspectives that might change one's judgment }\end{array}$ & 14 & 5.57 & 0.76 \\
\hline Children learned how they might understand someone else's judgment & 14 & 5.07 & 1.00 \\
\hline Children learned to think more critically about Development Aid & 13 & 3.77 & 1.48 \\
\hline $\begin{array}{l}\text { Children learned that it is important to cooperate in order to come to a } \\
\text { better understanding of the world }\end{array}$ & 13 & 4.46 & 1.20 \\
\hline Children learned to be more critical about their own way of thinking & 14 & 4.79 & 1.05 \\
\hline Children learned how Namibians think about the West & 14 & 3.79 & 1.72 \\
\hline Children learned about the effect the West has on Africa & 14 & 3.79 & 1.53 \\
\hline
\end{tabular}

Scale ranging from 1 ("strongly disagree") to 7 ("strongly agree")

Table 6 Content analysis of open interviews and excerpts

\begin{tabular}{|c|c|}
\hline Theme & Excerpts \\
\hline $\begin{array}{l}\text { Similarities and differences } \\
\text { between Namibians and us }\end{array}$ & $\begin{array}{l}\text { “...they're just like regular people like us, having the same } \\
\text { problems" } \\
\text { "...there are also children that can talk back. They are also human } \\
\text { beings and they also fight with their brothers and sisters and their } \\
\text { parents every once in a while. And they also play games. And they } \\
\text { do not only dance in little leather dresses or something. And clap } \\
\text { and stuff. That is not only what they do" }\end{array}$ \\
\hline Global interconnectedness & $\begin{array}{l}\text { "Realize that, even though we're so far apart, we're much more } \\
\text { interrelated than we think" } \\
\text { "... whatever happens there, resonances here, or has its influence on } \\
\text { what is going on here" }\end{array}$ \\
\hline $\begin{array}{l}\text { Accepting other perspectives as } \\
\text { valid }\end{array}$ & $\begin{array}{l}\text { "I learned the fact that even if people sort of have different ideas, } \\
\text { actually it's a good thing. It's a good thing because it sort of makes } \\
\text { you realize what your ideas are and actually sort of see that it's not } \\
\text { about this one or that one being right, but it's just about where } \\
\text { somebody comes from" } \\
\text { "... so be able, or be aware actually, not to scream too much about } \\
\text { you know, things you haven't experienced yourself or you haven't } \\
\text { seen. Unless you know, you've seen it" }\end{array}$ \\
\hline Thinking (critically) & $\begin{array}{l}\text { "I've learned, you know, it's dangerous to repeat things without } \\
\text { thinking, well, where did that idea actually come from?" }\end{array}$ \\
\hline Fairness & $\begin{array}{l}\text { "We tried to explain some concepts like fairness and equality and } \\
\text { discrimination and those kind of things" }\end{array}$ \\
\hline
\end{tabular}


Table 7 Descriptive statistics of pupils' opinion on the lessons given by students

\begin{tabular}{lccc}
\hline Opinion & Number & Mean & Standard deviation \\
\hline Opinion on the quality of lesson 1 & 175 & 7.34 & 1.89 \\
Opinion on the quality of lesson 2 & 176 & 7.72 & 1.83 \\
Opinion on the quality of lesson 3 & 176 & 7.46 & 1.86 \\
Opinion on the quality of lesson 4 & 157 & 8.32 & 1.84 \\
Opinion on how interesting the lessons were & 159 & 7.90 & 1.92 \\
Perception of how much (s)he has learned from the lessons & 145 & 7.26 & 2.31 \\
\hline
\end{tabular}

For each item scale ranges from 1 (lowest) to 10 (highest)

Table 8 Descriptive statistics of pupils' opinion on the lessons given by students in the third module

\begin{tabular}{llll}
\hline Descriptive statistic & Number & $\begin{array}{c}\text { Mean } \\
\text { Standard } \\
\text { deviation }\end{array}$ \\
\hline $\begin{array}{l}\text { I learned about differences and similarities between people of the world } \\
\text { I learned about fairness, inequality and discrimination. }\end{array}$ & 258 & 3.73 & 1.00 \\
$\begin{array}{l}\text { I learned how my life and the lives of people in countries away are } \\
\text { connected }\end{array}$ & 250 & 3.46 & 1.04 \\
$\begin{array}{l}\text { I learned that people can think very differently than I do myself, but we } \\
\text { can be both right }\end{array}$ & 250 & 3.65 & 1.05 \\
\hline
\end{tabular}

$1=$ strongly disagree; $5=$ strongly agree

\section{Conclusion}

With the increase in attention for global interconnectedness in higher education and the pressure on institutions of higher learning to engage with global challenges, the conceptualization, pedagogics and quality assurance of such efforts become very important. One conceptual challenge is to give meaning to global citizenship in a way that pays attention to both structural inequalities and intercultural competencies, to differences as well as similarities. Efforts should not reinforce existing stereotypes and binaries, but challenge students' worldviews and lead towards the co-construction of knowledge. From a pedagogical perspective, this calls for the opening up of a true dialogue, and the strengthening of efforts towards transformational learning. It also calls for moving beyond a mere focus on learning per se, but towards action. Such action has to be cognizant of the degree to which the local is constitutive of the global (and vice versa), and the ways in which engagement at home can be as important as engagement in faraway places. To be effective in transforming students and addressing global challenges, education for global citizenship thus has to be education for glocal citizenship. In addition, it is important to assess the actual impact of programs that are so different from regular university curricula.

The Going Glocal program described in this article is based on these above premises. Developed within a liberal arts and sciences setting, it builds on the history of civic engagement in the liberal arts tradition. The Global Perspective Scale, developed especially for this program, shows that the program had a positive effect on participating students in multiple domains: they gained a global perspective, global competence, a sense of social responsibility, and intercultural communication competencies. Due possibly to 
the small size of the intervention group (15), however, only the first two effects proved statistically significant. These findings suggest that as a result of the program students gained more open-minded attitudes to cultural difference, better understanding of other societies and other social perspectives, increased ability to critically assess global justice problems, and a deeper appreciation of the interactions between the local and global levels of social practices. The results of this program also confirmed that one of the challenges of GCE programs at the university level may be to find a balance between stimulating critical thinking and affording students a feeling of global efficacy, that is, in the sense that they can put global citizenship into practice (Andreotti 2006). Students sharing their experience with children in the local schools met with a positive reception and evaluation by those pupils, although there is no evidence that it made a solid impact on the children. For most of the university students, none of whom had any teaching experience, preparing and carrying out a class proved challenging. To strengthen this element of the program, students in subsequent rounds are receiving additional pedagogical preparation.

It is important to point out that such an education for global citizenship intervention might have an even more substantial effect on university students who attend institutions that are not international in character, and where enrolled students are not regularly exposed to cultural diversity on a daily basis. Such a hypothesis is worthy of additional research. Also, the voluntary nature of such programs calls for further investigation into their effects, especially since such GCE programs are prone to attract students who, by comparison to the general population, already have a more favorable disposition and competencies in this domain.

In all, the Going Glocal program provides an example of the conceptualization, pedagogics and measurement of an education for global citizenship program. Explicitly discussing the premises underlying such programs and their effects is important, if only to receive a certain measure of assurance that such programs achieve their stated outcomes for the individual students, the universities concerned, and the world at large.

Acknowledgments This work was supported by the Subsidies for Citizenship and Development Cooperation (SBOS) program of the Dutch Ministry of Foreign Affairs (Grant C0101).

Open Access This article is distributed under the terms of the Creative Commons Attribution 4.0 International License (http://creativecommons.org/licenses/by/4.0/), which permits unrestricted use, distribution, and reproduction in any medium, provided you give appropriate credit to the original author(s) and the source, provide a link to the Creative Commons license, and indicate if changes were made.

\section{References}

Abdi, A. (2008). Educating for human rights and global citizenship. Albany, NY: SUNY Press.

Andreopoulos, G. J., \& Claude, R. P. (1997). Human rights education for the twenty-first century. Pennsylvania: University of Pennsylvania Press.

Andreotti, V. (2006). Soft versus critical global citizenship education. Policy \& Practice: A Development Education Review, 3, 40-51.

Andreotti, V. (2011). The question of the "Other" in global citizenship education: A postcolonial analysis of telling case studies in England. In L. Shultz, A. Abdi, \& G. Richardson (Eds.), Global citizenship education in post-secondary institutions: Theories, practices, policies (pp. 140-157). New York: Peter Lang.

Andreotti, V., Biesta, G., \& Ahenake, C. (2015). Between the nation and the globe: Education for global mindedness in Finland. Globalisation, Societies and Education, 13(2), 246-259. 
Ang, S., Van Dyne, L., Koh, C., Ng, K. Y., Templar, K. J., Tay, C., \& Chandrashekhar, A. N. (2007). Cultural intelligence: its measurement and effects on cultural judgment and decision making, cultural adaptation and task performance. Management and Organization Review, 3(3), 335-371.

Ansell, N. (2005). Children, youth and development. London: Routledge.

Appiah-Padi, S. (2001). How study in North America shapes the global perspectives of African Students. Diversity Digest. http://www.diversityweb.org/digest/Sp01/study.html. Accessed 20 July 2012.

Arasaratnam, L. A. (2009). The development of a new instrument of intercultural communication competence. Journal of Intercultural Communication, 20. http://www.immi.se/jicc/index.php/jicc/article/ view/19. Accessed 20 July 2012.

Aristotle, \& Lord, C. (2013). Aristotle's politics. Chicago: University of Chicago Press.

Arndt, H. (1987). Economic development: The history of an idea. Chicago: University of Chicago Press.

Aronson, E. (1992). The return of the repressed: Dissonance theory makes a comeback. Psychological Inquiry, 3(4), 303-311.

Aronson, E. (1999). Dissonance, hypocrisy, and the self-concept. In E. Harmon-Jones \& J. Mills (Eds.), Cognitive dissonance: Progress on a pivotal theory in social psychology (pp. 103-126). Washington, DC: American Psychological Association.

Association of American Colleges \& Universities (2015). Essential Learning Outcomes. http://www.aacu. org/leap/essential-learning-outcomes. Accessed 2 July 2015.

Bauman, Z. (1998). Globalization: The human consequences. New York: Columbia University Press.

Benson, L., \& Harkavy, I. (2000). Higher education's third revolution: The emergence of the Democratic Cosmopolitan Civic University. Cityscape: A Journal of Policy Development and Research, 5(1), 47-57.

Boland, J. (2014). Orientations to civic engagement: Insights into the sustainability of a challenging pedagogy. Studies in Higher Education, 39(1), 180-195.

Comaroff, J., \& Comaroff, J. L. (1993). Modernity and its malcontents: Ritual and power in postcolonial Africa. Chicago: University of Chicago Press.

De Boeck, F., \& Honwana, A. (2005). Children and youth in Africa: Agency, identity and place. In A. Honwana \& F. De Boeck (Eds.), Makers and breakers: Children and youth in postcolonial Africa (pp. 19-29). Oxford: James Currey.

de Koeijer, V., Park, E., \& Sklad, M. (2015). Social representations of the 'African other' among participants of a global citizenship course in the Netherlands. Journal of Social Science Research, 7(3), 1394-1402.

Der-Karabetian, A., \& Metzer, J. (1993). The cross-cultural world-mindedness scale and political party affiliation. Psychological Reports, 72, 1069-1070.

Dewey, J., \& Boydston, J. (1980). The middle works of John Dewey, 1899-1924. Carbondale: Southern Illinois University Press.

Doer, N. M. (2013). Do 'global citizens' need the parochial cultural other? Discourse of immersion in study abroad and learning-by-doing. Compare: A Journal of Comparative and International Education, 43(2), 224-243.

Dower, N., \& Williams, J. (2002). Global citizenship: A critical introduction. London: Routledge.

Eurydice. (2005). Key Data on Education in Europe. http://eacea.ec.europa.eu/education/eurydice/key_ data_de.php. Accessed 20 July 2012.

Ferguson, J. (2006). Global shadows. Africa in the neoliberal world order. Durham and London: Duke University Press.

Festinger, L. (1957). A theory of cognitive dissonance. Stanford, CA: Stanford University Press.

Freire, P. (2004). Pedagogy of indignation. Boulder: Paradigm.

Geschiere, P., Meyer, B., \& Pels, P. (Eds.). (2008). Readings in modernity in Africa. Oxford: James Currey.

Guimaraes-Iosif, R. (2011). Rethinking citizenship education in higher education institutions through the lens of critical pedagogy: Educating local and global emancipated citizen. In L. Shultz, A. Abdi, \& G. Richardson (Eds.), Global citizenship education in post-secondary institutions: Theories, practices, policies (pp. 76-92). New York: Peter Lang.

Gusfield, J. (1967). Tradition and modernity: Misplaced polarities in the study of social change. The American Journal of Sociology, 72(4), 351-362.

Hanson, L. (2010). Global citizenship, global health, and the internationalization of curriculum: A study of transformative potential. Journal of Studies in International Education, 14, 70-88.

Inspectie van Onderwijs. (2006). Jaarwerkplan 2006. http://www.onderwijsinspectie.nl/binaries/content/ assets/Actueel_publicaties/2005/Jaarwerkplan+2006.pdf. Accessed 20 July 2012.

Jakubiak, C. (2012). English for the global: Discourses in/of English-language voluntourism. International Journal of Qualitative Studies in Education, 25(4), 435-451. 
Mannion, G., Biesta, G., Priestley, M., \& Ross, H. (2011). The global dimension in education and education for global citizenship: Genealogy and critique. Globalisation: Societies and Education, 9(3-4), 443-456.

Meillassoux, C. (1974). Development or exploitation: Is the Sahel famine good business? Review of African Political Economy, 1(1), 27-33.

Morais, D. B., \& Ogden, A. C. (2011). Initial development and validation of the Global Citizenship Scale. Journal of Studies in International Education, 15(5), 445-466.

Mufune, P. (2002). Youth problems in Namibia. In D. Le Beau \& R. Gordon (Eds.), Challenges for anthropology in the 'African renaissance': A southern African contribution. Windhoek: University of Namibia Press.

Naval, C., \& Jover, G. (2006). The research on moral and civic education in the Spanish educational theory: Evolution and current trends. Journal of Social Science Education, 4, 93-104.

NCDO. (2013). Nederlanders and Mondiaal Burgerschap. http://www.ncdo.nl/sites/default/files/Rapport\% 20Nederlanders\%20en\%20Mondiaal\%20Burgerschap\%202012.pdf. Accessed 15 June 2013.

Nussbaum, M. C. (1997). Cultivating humanity: A classical defense of reform in liberal education. Cambridge: Harvard University Press.

Nussbaum, M. (2002). Education for citizenship in an era of global connection. Studies in Philosophy and Education, 21, 289-303.

Nussbaum, M. (2010). Not for profit: Why democracy needs the humanities. Princeton: Princeton University Press.

Onderwijsraad. (2003). Onderwijs en burgerschap. http://www.onderwijsraad.nl/publicaties/2003/ onderwijs-en-burgerschap/item1251. Accessed 24 June 2012.

Peters, M. A., Britton, A., \& Blee, H. (2008). Global citizenship education: Philosophy, theory and pedagogy. Rotterdam: Sense.

Peterson, T. H. (2009). Engaged scholarship: Reflections and research on the pedagogy of social change. Teaching in Higher Education, 14(5), 541-552.

Print, M. \& Gray, M. (2000). Civics and citizenship education: An Australian perspective. www.abc.net.au/ civics/democracy/ccanded.html. Accessed 3 April 2011.

Probst, P., Deutsch, J., \& Schmidt, H. (Eds.). (2002). African modernities. Oxford: James Currey.

Richardson, G., De Fabrizio, L., \& Ansu-Kyeremeh, K. (2011). It's overwhelming and hard to articulate: Analyzing student narratives of an international global citizenship education field experience. In L. Shultz, A. Abdi, \& G. Richardson (Eds.), Global citizenship education in post-secondary institutions: Theories, practices, policies (pp. 95-107). New York: Peter Lang.

Robertson, R. (1995). Glocalization: Time-space and homogeneity-heterogeneity. In M. Featherstone, S. Lash, \& R. Robertson (Eds.), Global modernities (pp. 25-44). London: Sage.

Roth, M. J. (2014). Beyond the university: Why liberal education matters. New Haven: Yale University Press.

Sachs, W. (Ed.). (1992). The development dictionary: A guide to knowledge as power. London: Zed Books.

Sampson, D. L., \& Smith, H. P. (1957). A scale to measure world-minded attitudes. The Journal of Social Psychology, 45, 99-106.

Sen, A. (1999). Development as freedom. New York: Anchor Books.

Seneca, L. A., \& Costa, C. D. N. (1988). 17 Letters. Warminster: Aris \& Phillips.

Sherif, M., Harvey, O. J., Hood, W. R., Sherif, C. W. \& White, J. (1961/1988). The robbers cave experiment: Intergroup conflict and cooperation (Orig. pub. as Intergroup conflict and group relations). Middletown: Wesleyan University Press.

Shultz, L. (2011). Engaging the multiple discourses of global citizenship education within a Canadian university: Deliberation, contestation and social justice possibilities. In L. Shultz, A. Abdi, \& G. Richardson (Eds.), Global citizenship education in post-secondary institutions: Theories, practices, policies (pp. 13-24). New York: Peter Lang.

Shultz, L., Abdi, A., \& Richardson, G. (2011a). Global citizenship education and the role of the academy: A critical introduction. In L. Shultz, A. Abdi, \& G. Richardson (Eds.), Global citizenship education in post-secondary institutions: theories, practices, policies (pp. 1-13). New York: Peter Lang.

Shultz, L., Abdi, A., \& Richardson, G. (Eds.). (2011b). Global citizenship education in post-secondary institutions: Theories, practices, policies. New York: Peter Lang.

Tarrant, M. A., Rubin, D. L., \& Stoner, L. (2014). The added value of study abroad: Fostering a global citizenry. Journal of Studies in International Education, 18, 141-161.

Tchimino, M. (2008). Education for global citizenship. Zeitschrift für internationale Bildungsforschung und Entwicklungspädagogik, 31(3), 26-29.

ten Dam, G., Geijsel, F. P., Reumerman, R., \& Ledoux, G. (2011). Measuring citizenship competences of young people. European Journal of Education, 46(3), 354-372. 
UNDP. (1990). Human development report 1990. New York and Oxford: Oxford University Press.

UNESCO. (2014). Global citizenship education: Preparing learners for the challenges of the 21st century. Paris: Unesco.

UNESCO. (2015). Global citizenship education: Topics and learning objectives. Paris: UNESCO.

University Colleges Deans of the Netherlands. (2015). Statement on the role, characteristics, and cooperation of liberal arts and sciences colleges in the Netherlands. www.universitycolleges.info. Accessed 2 July 2015.

van der Wende, M. (2011). The emergence of liberal arts and sciences education in Europe: A comparative perspective. Higher Education Policy, 24, 233-253.

Weistra, S., Park, E., \& Sklad, M. (2015). Global Citizenship Education at a Dutch University College: Latin-American Liberation Psychology informing the construction of the 'other' and the self. Journal of Social Sciences Research, 7(3), 1385-1393.

Westheimer, J., \& Kahne, J. (2004). What kind of citizen? The politics of educating for democracy. American Educational Research Journal, 41, 237-269.

Wyn, J. \& White, R. (1997). The Concept of Youth. In Rethinking Youth (pp. 8-26). London: Sage. 